\title{
Holmes-Adie syndrome
}

\author{
Zubaida Sirang ${ }^{1}$, Irfan Jeeva² ${ }^{2}$ \\ 'University Hospital Galway, Ireland \\ ${ }^{2}$ Aga Khan University Hospital Karachi, Pakistan
}

\begin{abstract}
Holmes-Adie syndrome (HAS) is a rare neuro-ophthalmological disorder, which mostly presents in young females as a unilateral dilated pupil. We present a case of a 12 -year-old girl with bilateral tonic pupils. She had vermiform movement of the iris with segmental palsy, as well as loss of ankle jerks. The diagnosis was confirmed with pilocarpine $0.125 \%$ test, and she was symptomatically treated with the same drops.
\end{abstract}

KEY WORDS: Holmes-Adie syndrome; tonic pupils; light-near dissociation

Ophthalmol J 2019; Vol. 4, 44-45

\section{INTRODUCTION}

Holmes-Adie syndrome (HAS), as described by Adie in 1932, is a unilateral dilated pupil that is unresponsive to light, in association with lower limb hyporeflexia [1]. It is a rare neuro-ophthalmological disorder, more common in females, and it mostly presents unilaterally $[1,2]$.

\section{CASE REPORT}

A 12-year-old girl was referred to the eye clinic by her neurologist for the evaluation of bilateral dilated, non-reactive pupils. The patient had gone to a neurology clinic with complaint of headache. She had undergone complete neurological workup with MRI of the head, which was unremarkable.

Her past medical/surgical history was unremarkable and there were no ocular complaints. There was no history of drug use or trauma. She had no history of neurological deficits.

On ocular examination, the best-corrected visual acuity was $6 / 6$ in the right eye and 6/7.5 in the left eye. There was no ptosis with full extra-ocular movements bilaterally. Her pupils were mid-dilated with a diameter of $4.2 \mathrm{~mm}$ in the right eye and $5 \mathrm{~mm}$ in the left eye. The pupils were non-reactive to light but were reactive to accommodation.
On careful examination of her iris, we found that she had vermiform movement of the iris bilaterally, left more than right. There was sectoral iris palsy in the left eye at three o'clock. The rest of the anterior and posterior segment examination was unremarkable.

The right and left pupils showed significant response to $0.125 \%$ pilocarpine test with remarkable reduction of size to about $3 \mathrm{~mm}$ bilaterally in 20 minutes. On neurological examination, she had reduced ankle jerks bilaterally.

The diagnosis of HAS was made. The patient was sent home on pilocarpine $2 \%$ twice daily, and her headache improved on subsequent follow-up a week later.

\section{DISCUSSION}

Holmes-Adie syndrome refers to idiopathic tonic pupils with absent or decreased deep tendon reflexes. It is more common in females and presents unilaterally in $80 \%$ of cases, with a $4 \%$ chance of bilaterality each year [1-4]. Our patient had bilateral HAS with anisocoria.

Bilateral HAS has been discussed in the literature [5]. And in such cases it is important to differentiate it from generalised peripheral neuropathy, 
i.e. diabetic autonomic neuropathy [5]. Apart from hypersensitivity to diluted pilocarpine eye drops, vermiform iris movement, and reduced/absent tendon reflexes in HAS, there should be sectoral palsy and anisocoria $>1 \mathrm{~mm}$ [5]. A detailed medication history is important to rule out any use of mydriatic agents in a patient with bilateral dilated pupils. Also, Argyll Robertson pupil needs to be ruled out in bilateral cases of tonic pupils with light-near dissociation [6].

The first six cases of tonic pupils were reported by Adie in 1931, showing the relationship between deep tendon reflexes and tonic pupils [1]. Gordon Holmes in 1931 reported 54 cases of tonic pupils, 19 of which had diminished or absent tendon reflexes [4].

Holmes-Adie syndrome is further classified into complete and incomplete forms. In complete form, tonic pupil is associated with reduced or absent deep tendon reflexes in the lower limbs. In incomplete form, there is only tonic pupil or atypical phases of tonic pupil [1]. Our patient was an example of complete HAS.

The postulated pathophysiology in HAS is parasympathetic pathway defect due to viral neuropathy $[2-5,7,8]$. Ciliary muscle denervation and sphincter pupillae denervation lead to diminished accommodation and mydriasis, respectively [4]. Light-near dissociation of pupils occurs due to aberrant degeneration. Achilles reflexes are the most frequently affected reflexes and are thought to be due to spinal ganglion defect [4].

Patients with HAS generally present with blurring of near vision as a main complaint $[4,7,8]$. They also have poor light response, slow response to near vision with light-near dissociation, hypersensitivity to cholinergic eye drops, and decreased tendon reflexes [9]. Sectoral palsy of the iris along with vermiform movement can occur in HAS $[6,7]$. Tonic pupil may become miotic with the passage of time, known as "little old Adie pupil".
In the literature another very rare entity of HAS has been described, known as Ross syndrome. It is defined as HAS with segmental anhidrosis or hyperhidrosis [9].

Holmes-Adie syndrome has been suggested to be associated with Sjögren's disease, temporal arteritis, and rheumatoid arthritis, and it can also present as a paraneoplastic syndrome in association with lung and breast malignancies [10]. Holmes-Adie syndrome is also believed to occur in association with autoimmune hepatitis and coeliac disease [11]. Once the diagnosis of HAS has been established, the patients mostly need reassurance with short-term pilocarpine eye drops.

\section{REFERENCES}

1. Adie WJ. Tonic pupils and absent tendon reflexes: a benign disorder sui generis; its complete and incomplete forms. Brain. 1932; 55(1): 98-113, doi: 10.1093/brain/55.1.98.

2. Martinelli P. Holmes-Adie syndrome. The Lancet. 2000; 356(9243): 1760-1761, doi: 10.1016/s0140-6736(00)03216-5, indexed in Pubmed: 11095273.

3. Guaraldi P, Mathias CJ. Progression of cardiovascular autonomic dysfunction in Holmes-Adie syndrome. J Neurol Neurosurg Psychiatry. 2011; 82(9): 1046-1049, doi: 10.1136/jnnp.2009.195917, indexed in Pubmed: 20562402.

4. Siddiqui AA, Clarke JC, Grzybowski A. William John Adie: the man behind the syndrome. Clin Exp Ophthalmol. 2014; 42(8): 778-784, doi: 10.1111/ceo.12301, indexed in Pubmed: 24533698.

5. Bremner FD, Smith SE. Bilateral tonic pupils: Holmes Adie syndrome or generalised neuropathy? Br J Ophthalmol. 2007; 91(12): 1620-1623, doi: 10.1136/bjo.2007.118968, indexed in Pubmed: 17584996.

6. Thompson HS, Kardon RH. The Argyll Robertson Pupil. J Neuroophthalmol. 2006; 26(2): 134-138, doi: 10.1097/01. wno.0000222971.09745.91, indexed in Pubmed: 16845316.

7. Bilateral tonic pupils: Holmes-Adie syndrome or generalised neuropathy? Br J Ophthalmol. 2007; 91(12): 1620-1623, doi: 10.1136/ bjo.2007.118968, indexed in Pubmed: 17584996.

8. Thompson HS. Adie's syndrome: some new observations. Trans Am Ophthalmol Soc. 1977; 75: 587-626, indexed in Pubmed: 613531.

9. Moeller JJ, Maxner CE. The dilated pupil: an update. Curr Neurol Neurosci Rep. 2007; 7(5): 417-422, indexed in Pubmed: 17764632.

10. Mayer H. Bilateral tonic pupils secondary to Ross syndrome: a case report. J Optom. 2014; 7(2): 106-107, doi: 10.1016/j.optom.2013.06.005, indexed in Pubmed: 24766868.

11. Csak T, Folhoffer A, Horvath A, et al. Holmes-Adie syndrome, autoimmune hepatitis and celiac disease: a case report. World J Gastroenterol. 2006; 12(9): 1485-1487, doi: 10.3748/wjg.v12.i9.1485, indexed in Pubmed: 16552828. 